\title{
СКРОМНОСТЬ КАК СОЦИОКУЛЬТУРНАЯ ЦЕННОСТЬ В РУССКОЙ И КИТАЙСКОЙ ЯЗЫКОВОЙ КАРТИНЕ МИРА
}

\section{MODESTY AS A SOCIO-CULTURAL VALUE IN THE RUSSIAN AND CHINESE LANGUAGE PICTURE OF THE WORLD}

Zhang Nan

Summary: Within the framework of this article, the problems concerning the issues of linguoculturalism are considered in detail. These issues are considered from the point of view of science and methodology in relation to the teaching of the Russian language. The subject of this article is the concept «modesty» both in Russian and Chinese languages. The material base is the synonymic series, which are used in both languages and the materials of the experiment of associative nature.

Keywords: modesty, concept, PRC, Russia, culturology.
$\mathrm{H}$ а текущий момент одним из ключевых направлений лингвистической культурологии является анализ лингвистическо-культурологического характера, для этого нужно четко понимать как терминология, так и методологию по рассматриваемому вопросу. Данный вопрос является проблемным по причине того, что ряд понятий по разному трактуются. Тоже самое происходит с методами исследования. Это не удивительно, так как изучения в рассматриваемой области находятся на границе различных научных областях. Наличие материала в необходимых объемах, а так же проведенный должным образом анализ сопоставительного и экспериментального характера на актуальном ныне срезе национальных языков дает возможность произвести выводы на объективном уровне, о каком либо факте лингвистической культуры и ее различных сторонах.

В том случае, если исходить из термина концепт, как единицы которая входит в концептсферу[1] и языковой картины мира , в этом случае концепт это не что иное, как средства как языкового, так и не языкового характера, которые так или иначе иллюстративно показывают, уточняют и даже развивают содержание оного.

В тех текстах, где иллюстрируется концепт посредством фразеологизма, паремии и т.д., собственное имя концепта может отсутствовать, при этом раскрытие сути осуществляется посредством характеристик понятийного, образного или оценочного характера. В данном случае гораздо удобнее применять расширительно термин концептуальный код, который объединяет в группу по

\author{
Чжан Нань \\ Аспирант, Московский государственный \\ университет им. М.В. Ломоносова \\ 13034966031@163.com
}

Аннотация: В рамках данной статьи подробно рассмотрена проблематика касаемо вопросов лингвокультурологии. Данные вопросы рассматриваются с точки зрения науки и методологии относительно преподавания РКИ. Предмет исследования данной статьи является концепт "скромность", как в русском, так и в китайском языке. Материальной базой выступают синонимические ряды, которые применяются в обоих языках и материалы эксперимента ассоциативного характера.

Ключевые слова: скромность, концепт, КНР, Россия, культурология.

тематическому признаку слова, а так же антонимические и синонимические ряды, которые в свою очередь могут целиком или частями быть подвержены вторичной метафоризации в лингвистической культуре национального характера (солод - сладкий - сладкая улыбка - в русской лингвокультуре 'угодливая', тогда как в китайской лингвокультуре - 'приятная').

Согласно теории В.И. Карасика [2], концепт можно описать по целому ряда методик:

- Дефинирование

- Контекстуальный анализ

- Этимологический анализ

- Паремиологический анализ посредством норм поведения

- Анкетирование[3].

В различных языках ряд явлений имеет наименование детального характера, при этом образуется некая система лексического и фразеологического характера, при этом иные обозначаются всего одним словом. В культурах, которые мы рассматриваем в рамках данной статьи присутствуют данные концепты, однако наличествует и разница, которая проявляется в количественном и комбинаторном выборе признаков.

С точки зрения Степанова Ю.С.[4], структура концепта содержит в себе все то, благодаря чему он становится фактом культуры:

- Исходная форма с этимологией

- Актуальные ассоциации

- Оценки. 
Ценности, которые определяют поведенческие компетенции граждан, это ключевая часть картины мира языкового характера.

С точки зрения лингвистики, описание может быть осуществлено посредствам концептов культурного характера тех, которые многомерны, имеют культурную значимость.

Если говорить о рассматриваемых концептах, нужно рассмотреть как минимум три их стороны:

$$
\begin{aligned}
& \text { - Образ } \\
& \text { - Понятие } \\
& \text { - Ценность }
\end{aligned}
$$

Делая выводы о результатах сопоставления концепта "скромность" в рассматриваемых культурах, нужно сказать, что ранее подобные изучения уже существовали, однако сопоставление с имеющимися в лингвистической культуре КНР данными, демонстрирует интересные сведения об отечественных взглядах на скромность.

Сложность изучения рассматриваемого концепта заключается в тех характеристиках, которые он в себя включает, как они переплетаются меж собой и насколько разняться их представления в лингвистических культурах рассматриваемых стран.

Исходя из вышесказанного при проведении анализа концептуального характера использовались методики:

- Анализ словарных дефиниций

- Аппликация словарных статей

- Анализ сопоставительного характера

- Контекстуальный анализ

- Ассоциативный анализ

Рассматриваемый концепт обладает большой степенью концептуализации в лингвокультуре КНР и небольшой в отечественной лингвокультуре.

Этимология скромности в нашей лингвокультуре относительно конкретного человека, это не что иное как навыки умений находиться в конкретных границах, то есть, согласно внешней форме, проявление в поведении.

Изначально те иероглифы, которые представляют собой скромность в языке КНР, это описание внутреннего состояния, которое может быть выражено в словесной форме или же поступках.

Ключевые характеристики термина скромность, в том, как его трактуют словари КНР и РФ сильно схожи, а вот имеющиеся различия и демонстрируют, насколько концептуальны рассматриваемые концепты в культурах.

Ядром концепта выражено качество личности поло- жительного характера, которое заключается в том, что бы демонстративно не показывать имеющиеся заслуги, не являться высокомерным, в русском языке это демонстрируется посредством конструкций отрицательного характера.

То есть ядро отечественного концепта не содержит ключевой понятийной характеристики, не смотря на наличие образа и оценки скромного поведения.

Если говорить о существующем ныне срезе отечественной лингвокультуры, синонимы рассматриваемого концепта, как то кротость или же смирение, на текущий момент выведены из речи разговорного характера и сохранены в речи религиозного толка, то есть концепт данного термина относится к иному дискурсу.

Сегодня в отечественной лингвокультуре так же фактически отсутствует оппозиция рассматриваемого термина.

Контекстуальные синонимы, связанные с внутренней формой или этимологией «ограничения» - умеренность (мера), сдержанность (держать), частичная скромность (край) и особенно конечность (граница) так или иначе принимают дополнительное значение скованности, строгости, несвободы, так что нечто негативное, запирающее человека в жесткие нормативные рамки, изначально кажется не свойственным человеческой природе, русскому национальному сознанию и российское национальное поведение. В этом отношении полярность структуры ядра концепта 'скромность' в русской лингвокультуре осложняется наслоением маргинальных доменов, что определяется дискурсивными, стилистическими и семантическими особенностями концепта, проявляющимися в синонимических рядах и сочетаниях слов. В контексте русской художественной литературы очевидно, что концепт «скромность» в сочетании с другими концептуальными человеческими качествами может иметь как положительное, так и ироническое, частично или полностью отрицательное значение. Это отражает особенность русской лингвистической культуры: понятие может содержать взаимодополняющие, противоположные или даже взаимоисключающие категории. С одной стороны, скромность является положительным качеством, сочетающимся с умом, талантом и соответствующим социальным поведением, а с другой стороны, содержит ироническую оценку своих качеств, сочетающуюся с трудолюбием, низким профессиональным статусом или низким материальным благосостоянием и благоразумием. В русском языке и культуре существуют образы «скромных» цветов: не пышных, не ярких, скорее полевых, «скромных» цветов (бледных, серых, темных), которые широко используются при создании художественных образов. Контекст китайского романа дает только положительные образы, только позитивные 
образы и оценочные характеристики концепта «скромность», даже если эти образы (с точки зрения русского языка и культуры) связаны с унижением, оскорблением, принижением социального или интеллектуального статуса скромного человека. Оценочные признаки образа расширяют область действия концептуальных признаков, создавая образ "благородного ", внешние проявления поведения которого полностью соответствуют внутренней этической регуляции скромности и не противоречат друг другу.

\section{ЛИТЕРАТУРА}

1. Карасик В.И. Языковой круг: личность, концепты, дискурс. Волгоград: Перемена, 2012.

2. Кошманова О.В. Ценностная характеристика концепта «скромность» в русской, американской и иранской лингвокультурах // Язык, перевод и межкультурная коммуникация: материалы регион. науч. конф. 13-14 окт. 2005 г. Астрахань: Астрах. ун-т, 2015.

3. Лихачев Д.С. Концептосфера русского языка // Изв. АН. Сер. литературы и языка. Т. 52. № 1. 2013.

4. Степанов Ю.С. Константы: Словарь русской культуры. Опыт исследования. М. : Яз. рус. культуры, 2017.

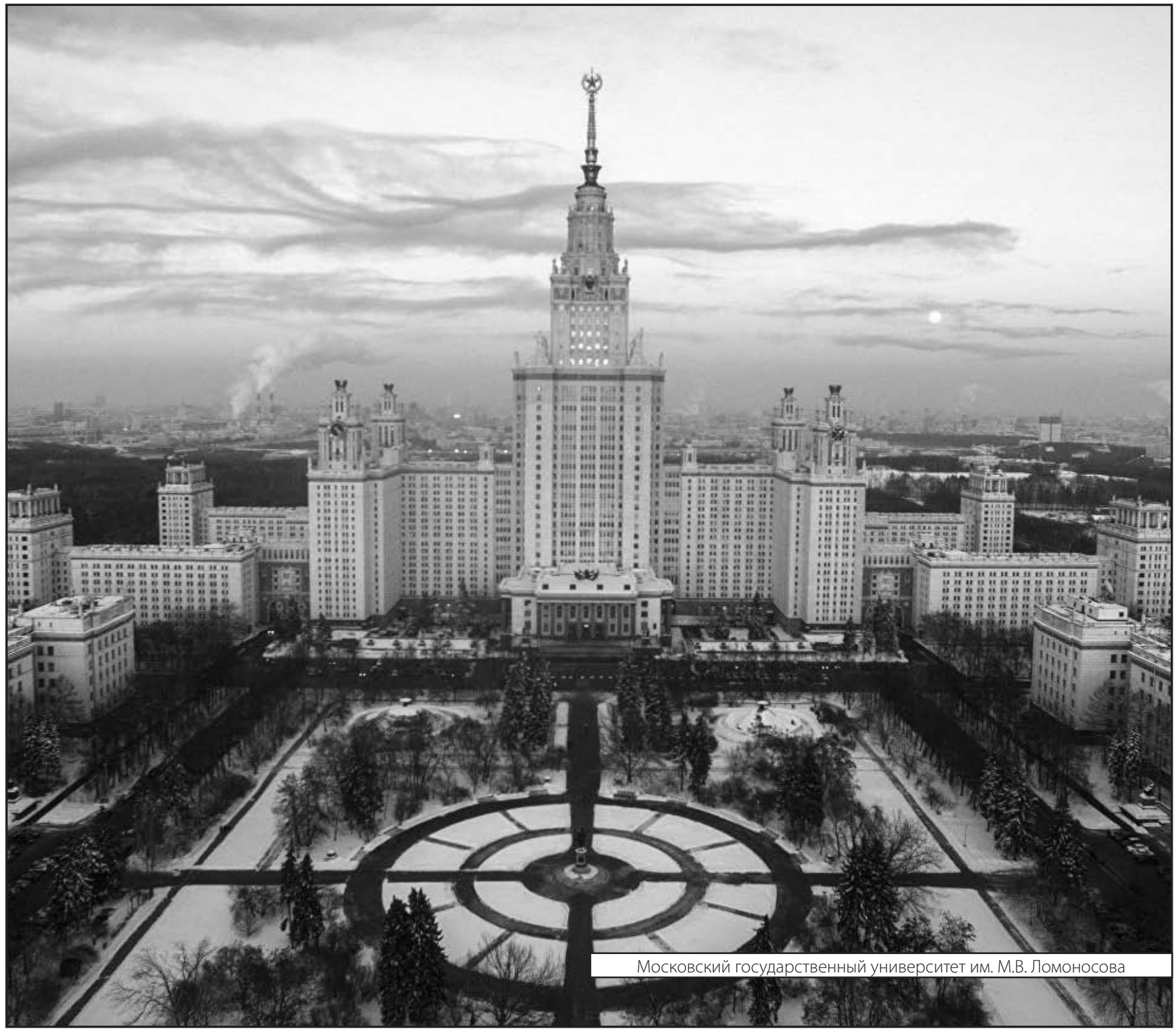

